\title{
Genomic DNA isolation of Acrocomia aculeata (Arecaceae) from leaf and stipe tissue samples for PCR analysis
}

\author{
E.C.M. Lanes, C. Nick, K.N. Kuki, R.D. Freitas and S.Y. Motoike \\ Departamento de Fitotecnia, Universidade Federal de Viçosa, \\ Viçosa, MG, Brasil \\ Corresponding author: E.C.M. Lanes \\ E-mail: edercml@gmail.com
}

Genet. Mol. Res. 12 (3): 3905-3911 (2013)

Received January 21, 2013

Accepted July 23, 2013

Published September 23, 2013

DOI http://dx.doi.org/10.4238/2013.September.23.9

\begin{abstract}
Macaw palm, Acrocomia aculeata is an oleaginous species of the Arecaceae family; it has been identified as one of the most promising plants for sustainable production of renewable energy, especially biodiesel. We developed an efficient protocol of genomic DNA extraction for A. aculeata using leaf and stipe tissues, based on the cationic hexadecyltrimethylammonium bromide method, and we evaluated the quantity, purity, and integrity of the resultant DNA. We also determined whether these procedures interfere with PCR amplification using SSR molecular markers. The lowest concentration of DNA was obtained from stipe tissues $(135 \mathrm{ng} / \mu \mathrm{L})$, while fresh leaf tissues provided the highest concentration of DNA (650 ng/ $\mu \mathrm{L})$. Good quality DNA was obtained from fresh leaf, lyophilized leaf, and stipe tissues (relative purity, 1.79-1.89 $\mathrm{nm}$ ). Differences in quantity and quality of DNA extracted from different tissues did not interfere with general patterns of PCR amplification based on SSR markers.
\end{abstract}

Key words: Molecular marker; Oleaginous species; Macaw palm; Optimization DNA; PCR amplification; SSR 


\section{INTRODUCTION}

Macaw palm, Acrocomia aculeata (Jacq). Lodd. ex Martius, is an oleaginous species of the family Arecaceae. Commonly found in the tropical Americas, this palm tree is widespread in Brazil, with the highest densities found in the states of Minas Gerais, Goiás, Mato Grosso and Mato Grosso do Sul (Henderson et al., 1995). This palm has been identified as one of the most promising plants for the sustainable production of renewable energy, especially biodiesel, based on its high yields and resilience to adverse environmental conditions. Furthermore, it shows several possibilities for the food and cosmetic industries (Motoike and Kuki, 2009; Abreu et al., 2011).

However, in areas where $A$. aculeata is exploited, it is often carried out in a rudimentary way, resulting in a low yield and poor quality products. The breeding program for this species is one of the key strategies to ensure its production sustainability (Moura et al., 2009; Manfio et al., 2012). In this context, the application of molecular biology techniques has been an essential tool for the studies of germplasm conservation, association mapping, phylogeny, mapping of QTL (quantitative trait loci) and analysis of population and structure. However, the success of these studies is very dependent on an efficient extraction of DNA (Borges et al., 2012).

High quality DNA samples must be free of contaminants, or otherwise, they can ruin the reactions. Most of all, the impurities can interfere in the action of restriction enzymes, Taq polymerase in PCR reactions or electrophoretic separation of DNA fragments (Molinari and Crochemore, 2001). An efficient protocol for DNA isolation provides good conditions for PCR amplification allowing reproducibility and clear bands. Several protocols for DNA extraction have been optimized and successfully applied to plant species (Shahzadi et al., 2010). The lyophilization of the tissue, if used prior to the extraction of DNA, could reduce degradation problems in the samples, which allows storage and preservation of the plant tissue for a longer period of time (Nunes et al., 2011).

Besides, sampling foliar tissue may present some restrictions especially in mature palm trees due to their height. Mature palm trees are usually 16 to $20 \mathrm{~m}$ tall, which is an obstacle for efficient leaf sampling especially in the wild. As an alternative to the leaf, samples of stipe tissue can be easily obtained at the ground level. However, stipe tissue is more susceptible to oxidation due to its high phenolic contents.

The objective of this study was to standardize an efficient protocol for genomic DNA extraction from leaf (fresh and lyophilized) and stipe tissues of $A$. aculeata for genetic studies by using simple sequence repeat (SSR) molecular markers.

\section{MATERIAL AND METHODS}

\section{Plant material}

Foliar and stipe samples of $A$. aculeata were collected from the Zona da Mata and Central part of Minas Gerais State, as described below:

Foliar material: Leaflets were collected from non-senescent healthy fronds. They were excised from the rachis and immediately placed in liquid nitrogen and sent to the Laboratório de Biotecnologia e Melhoramento Vegetal - DFT/ UFV, in Viçosa, MG. As soon as they arrived in the laboratory, a group of samples were randomly selected for immediate DNA 
extraction. Another group of samples was lyophilized for $72 \mathrm{~h}$ and then stored for 30 days in the freezer at $-20^{\circ} \mathrm{C}$.

Stipe material: Stipe material was obtained after a cleanup of the trunk to eliminate debris, thorns and petiole remains until the stipe surface became visible. With a sharp disinfected blade the outer fibrous layer of the stipe was removed exposing the inner part of the organ. A sample of approximately $0.5 \mathrm{~cm}$ in thickness and $0.8 \mathrm{~cm}$ in diameter was then withdrawn with a cork cutter, transferred to an Eppendorf tube and placed in liquid nitrogen (Figure 1).

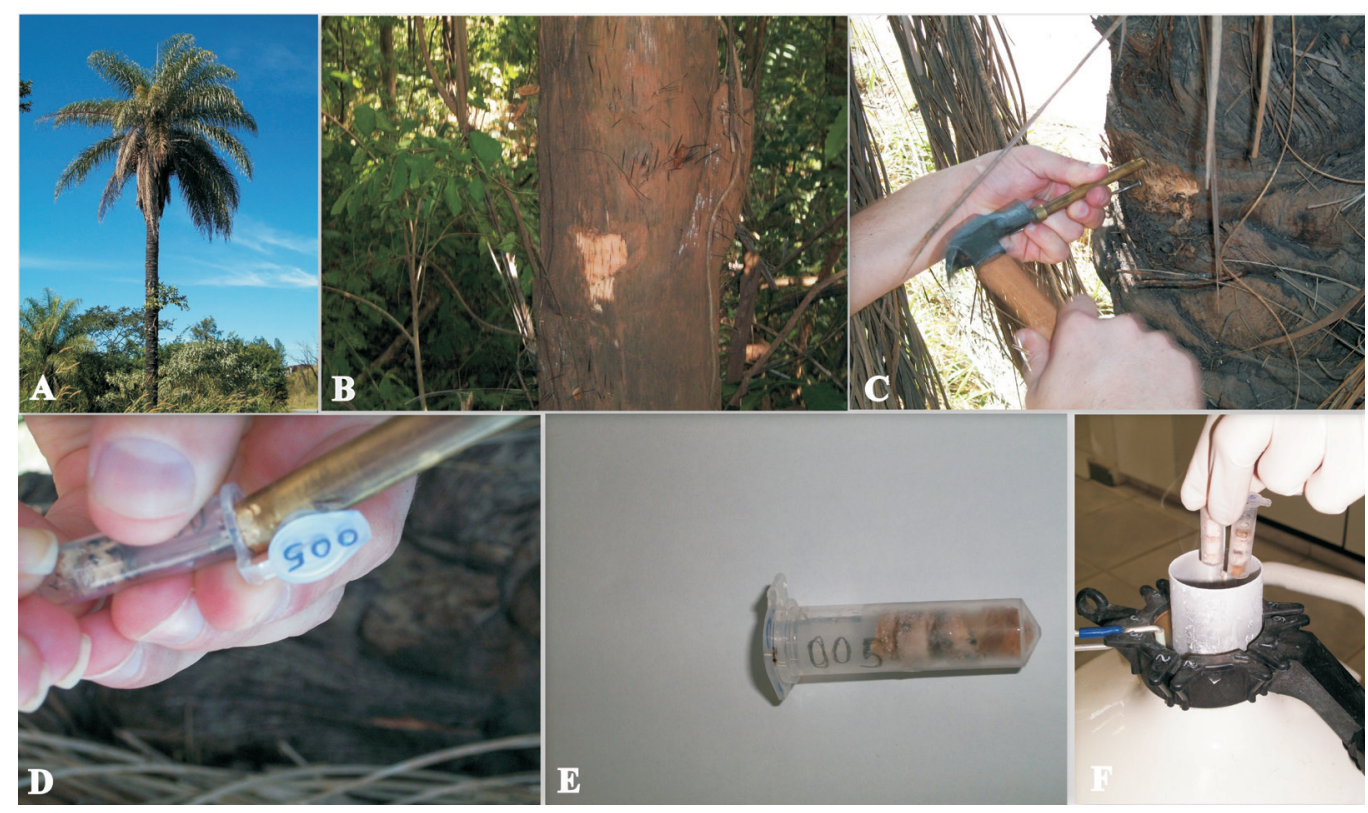

Figure 1. A. Macaw palm plant in its natural habitat. B. Exposed trunk after removal of debris. C. Stipe sample harvest with cylindrical cork cutter. D. and E. Stipe sample in Epperdorf tube. F. Storage of samples in liquid nitrogen.

\section{Protocol}

The protocol for DNA extraction was based on that of Doyle and Doyle (1990) with main modifications that followed the works of Faleiro et al. (2002) and Dellaporta et al. (1983). The modifications involved the concentration of cationic hexadecyltrimethylammonium bromide (CTAB); the exclusion of 2-mercaptoetanol and the addition of sodium dodecyl sulfate (SDS). The modified CTAB extraction buffer consisted of $0.11 \mathrm{M}$ Tris- $\mathrm{HCl}(\mathrm{pH} 8.0), 55 \mathrm{mM}$ EDTA (pH 8.0), $1.4 \mathrm{M} \mathrm{NaCl}$, and CTAB (2.8\%, w/v). A supplement of SDS $(1.82 \%$, v/v) was added to each sample after the buffer. The steps for both foliar and stem samples followed very similar steps, and the final protocol is described below.

\section{Procedures for DNA extraction, quantification, and quality determination}

For the procedures, $200 \mathrm{mg}$ leaf or stipe tissue were used.

1. The leaflets, previously cut into small pieces, were placed in $2.0-\mathrm{mL}$ microtubes 
and hand mashed using a glass pestle with liquid nitrogen, until a powdery material was obtained. Immediately after maceration, $1.0 \mathrm{~mL}$ of extraction buffer was added to each microtube.

2. For stipe tissue, grinding it with a mortar and pestle before the addition of liquid nitrogen, helped to obtain a fine powder.

3. After grinding, $100 \mu \mathrm{L} 20 \% \mathrm{SDS}(\mathrm{w} / \mathrm{v})$ were added with constant mixing to obtain a homogeneous mixture.

4. The mixture samples, containing leaf or stem tissue, were incubated at $65^{\circ} \mathrm{C}$ for 60 $\mathrm{min}$; the microtubes were inverted every $10 \mathrm{~min}$.

5. After incubation, the samples were cooled down to room temperature for about $5 \mathrm{~min}$.

6. A volume of $450 \mu \mathrm{L}$ chloroform-isoamyl alcohol $(24: 1, \mathrm{v} / \mathrm{v})$ was added; microtubes were inverted for $10 \mathrm{~min}$.

7. The samples were then centrifuged at $15,682 \mathrm{~g}$ for $10 \mathrm{~min}$.

8. The aqueous phase $(900 \mu \mathrm{L})$ was transferred to a new microtube.

9. The steps 4,5 and 6 were repeated once but transferring only $700 \mu \mathrm{L}$ of aqueous phase to a new microtube. The remained material was discarded.

10. To precipitate the nucleic acids, cold isopropanol ( 1 volume of $700 \mu \mathrm{L})$ was added to the collected aqueous phase and then placed in a freezer at $-20^{\circ} \mathrm{C}$ for at least $2 \mathrm{~h}$.

11. After standing in the freezer, the mixture was centrifuged at $15,682 \mathrm{~g}$ for $10 \mathrm{~min}$ and the supernatant discarded. (Note: stipe samples were centrifuged at 16,168 $g$ for $15 \mathrm{~min}$ to allow pellet formation and its fixation to the bottom of tube).

12. The pellet was washed twice with $(300 \mu \mathrm{L})$ cold $70 \%(\mathrm{v} / \mathrm{v})$ ethanol and once with cold $95 \%(\mathrm{v} / \mathrm{v})$ ethanol.

13. The pellet was air-dried for $1 \mathrm{~h}$ at room temperature.

14. After cooling, the pellet was dissolved in $70 \mu \mathrm{L} 0.1 \mathrm{X}$ TE buffer with RNAse (4 $\mathrm{mL} 10 \mathrm{mg} / \mathrm{mL}$ RNAse solution per $\mathrm{mL} 0.1 \mathrm{X} \mathrm{TE}$ ) and incubated at $65^{\circ} \mathrm{C}$ for $10 \mathrm{~min}$.

15. An aliquot $(2 \mu \mathrm{L})$ of each sample was submitted to electrophoresis on a $1 \%$ agarose gel in 1X TBE buffer containing $10 \mathrm{mg} / \mathrm{mL}$ ethidium bromide.

16. The concentration of DNA was measured using spectrophotometry, assuming an equivalency of $50 \mu \mathrm{g} / \mathrm{mL}$ for $1 \mathrm{U}$ absorbance at $260 \mathrm{~nm}$.

17. DNA quality was evaluated by the $\mathrm{A}_{260} / \mathrm{A}_{280} \mathrm{~nm}$ ratio.

18. The DNA samples were stored at $-20^{\circ} \mathrm{C}$ until further use.

\section{PCR amplification and gel electrophoresis}

Amplification reaction was conducted using an Applied Biosystems Veriti ${ }^{\mathrm{TM}}$ thermal cycler(AppliedBiosystems). The SSR locus used were: i)Aacu07(F:ATCGAAGGCCCTCCAA TACT and R: GAAATAAGGGGACCCTCCAA) and ii) Aacu12 (F: GAATGTGCGTGCTCA AAATG and R: AATGCCAAGTGACCAAGTCC) (Nucci et al., 2008). The total volume of each reaction was $20 \mu \mathrm{L}$ containing $30 \mathrm{ng}$ genomic DNA, $100 \mu \mathrm{M}$ dNTPs, $0.1 \mu \mathrm{M}$ primer SSR, $0.5 \mathrm{U}$ Taq polymerase, and $1 \mathrm{X}$ PCR buffer. The thermocycler was programmed for one initial denaturation step of $5 \mathrm{~min}$ at $94^{\circ} \mathrm{C}$ and 30 cycles of $1 \mathrm{~min}$ at $94^{\circ} \mathrm{C}, 1 \mathrm{~min}$ at the specific annealing temperature for each primer pair, and $1 \mathrm{~min}$ at $72^{\circ} \mathrm{C}$ for extension, and a final extension at $72^{\circ} \mathrm{C}$ for $8 \mathrm{~min}$. The resulting DNA fragments from the amplification were separated by electrophoresis on $6.0 \%$ denaturing polyacrylamide 
(w/v) gels [(19:1) acrylamide/bis-acrylamide (Bio-Rad), 7.5 M urea, 5.0X TBE], using the electrophoresis system "Sequi-Gen GT" (Bio-Rad) in 1X TBE buffer (0.09 M Tris base, $0.09 \mathrm{M}$ boric acid and $2 \mathrm{mM}$ EDTA, $\mathrm{pH}$ 8.0). The gels were visualized by silver nitrate staining.

\section{RESULTS AND DISCUSSION}

The DNA was successfully obtained from leaf and stipe samples of $A$. aculeata. The average concentration of DNA determined in a spectrophotometer obtained from fresh leaf samples was $650 \mathrm{ng} / \mu \mathrm{L}$ and from stipe was $135 \mathrm{ng} / \mu \mathrm{L}$ (Table 1). The leaf sample yielded 4.8 times more DNA than stipe tissue. The DNA yield difference between fresh leaf and stipe was confirmed in the analyses of the band pattern of DNA on agarose gel electrophoresis (Figure 2) where the bands of stipe DNA appeared less intense than the bands of leaf DNA (Figure 2a). Although less DNA had been extracted from stipe samples, the amount of DNA recovered was more than that expected. Usually CTAB DNA extraction protocols yield DNA with a concentration of 10-200 $\mathrm{ng} / \mu \mathrm{L}$ extracted from 50-200 $\mathrm{mg}$ of leaf tissue (Ferreira and Grattapaglia, 1998). This result demonstrated the efficiency of the suggested protocol for leaf and stipe tissues.

Table 1. Quantification and purity of genomic DNA using $200 \mathrm{mg}$ from leaf (lyophilized and fresh) and stipe tissues of Acrocomia aculeata.

\begin{tabular}{lccc}
\hline Samples & Quantification $(\mathrm{ng} / \mu \mathrm{L})$ & Total of DNA $(\mu \mathrm{g})$ & $\mathrm{Ratio}\left(\mathrm{A}_{260} / \mathrm{A}_{280} \mathrm{~nm}^{*}\right)$ \\
\hline Stipe & 135 & 9.45 & $1.89 \pm 0.17^{*}$ \\
Fresh leaf & 650 & 45.50 & $1.79 \pm 0.20$ \\
Lyophilized leaf & 603 & 42.18 & $1.86 \pm 0.24$ \\
\hline
\end{tabular}

$*$ SD for $n=4$.

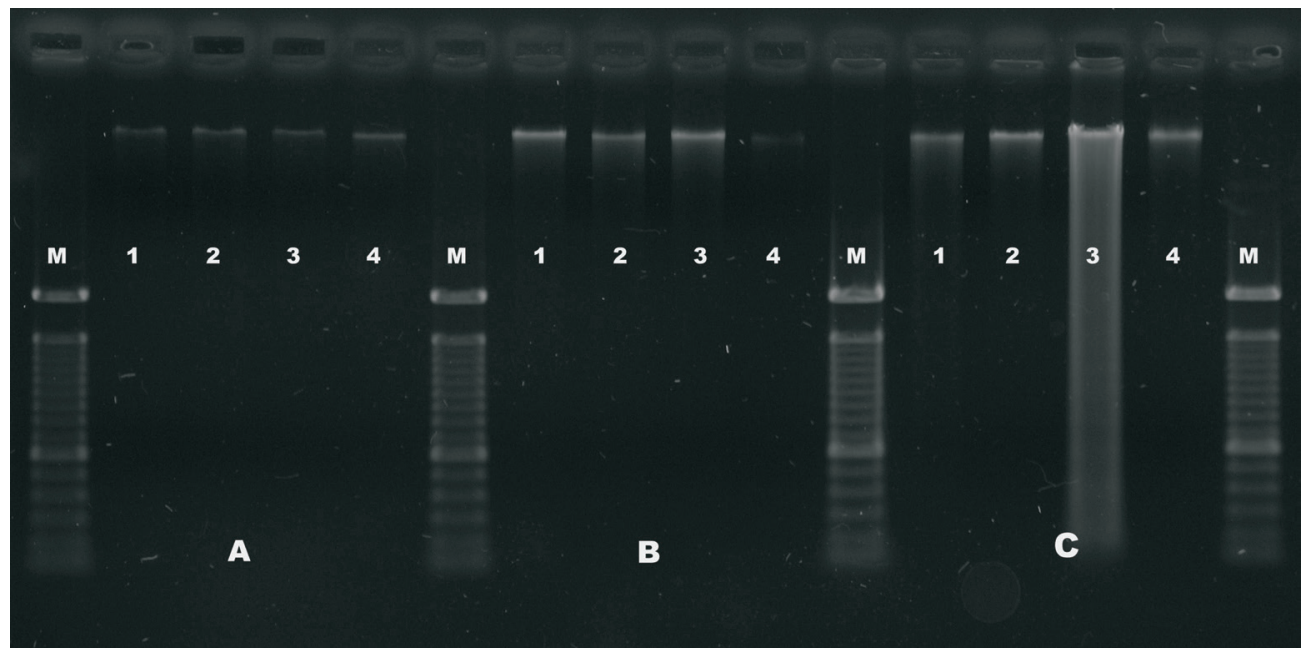

Figure 2. Genomic DNA extracted from specimens of Acrocomia aculeata, using Doyle and Doyle protocols modified. A. Stipe tissues, B. Fresh leaf tissues, and C. lyophilized leaf tissues. Lanes 1-4 of A., B. and C. correspond to their respective tissues. Lane $M=200$-bp DNA ladder, 
Regardless of quantity, the quality of the DNA extracted from the fresh leaf and the stipe was high, with a relative purity of the DNA varying from 1.79 to 1.89 . Pure DNA is supposed to show an $\mathrm{A}_{260} / \mathrm{A}_{280} \mathrm{~nm}$ ratio of 1.8-2.0. A lower ratio $(<1.6)$ indicates contamination with protein and/or other contaminants, whereas a ratio higher than 2.0 indicates that the samples may be contaminated with phenol or chloroform (Barbosa, 1998; Sambrook and Russel, 2001).

The quality and quantity of DNA recovered from lyophilized leaf tissue determined with a spectrophotometer were similar to that obtained with DNA from fresh leaf tissue (Table 1). However, in agarose gel electrophoresis, the DNA from lyophilized leaf tissue showed vertical drags indicating possible DNA fragmentation (Figure 2c). However, this pattern did not interfere with PCR since all three sources of DNA obtained by the modified CTAB extraction protocol were successfully amplified by PCR using SSR primers (Figure 3).

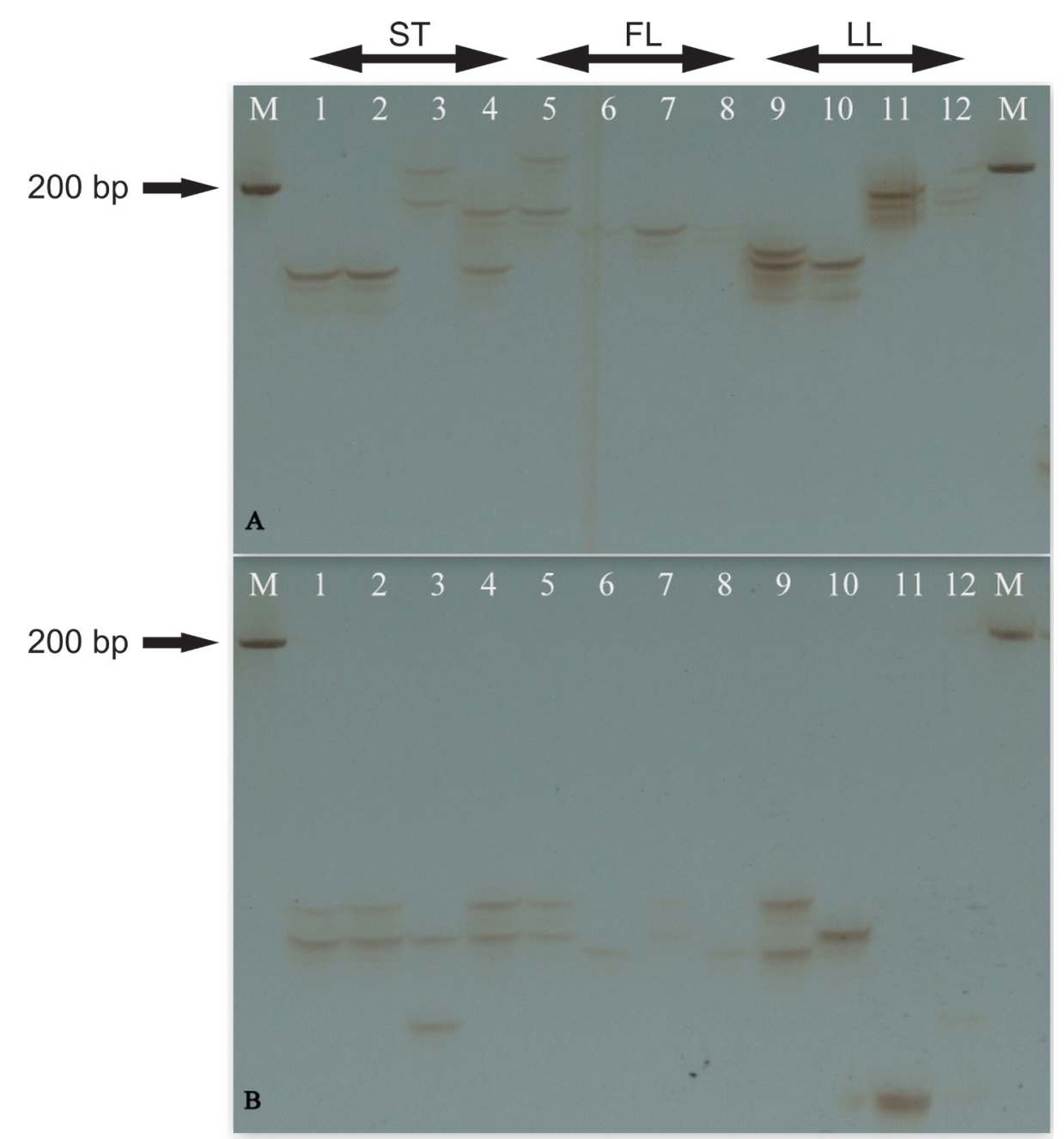

Figure 3. Standard SSR bands generated with primers Aacu12 (A) and Aacu07 (B). ST = Stipe tissues (Lanes 1-4); $\mathrm{FL}=$ fresh leaf tissues (Lanes 5-8); $\mathrm{LL}=$ lyophilized leaf tissues (Lanes 9-12). $\mathrm{M}=$ 200-bp DNA ladder. 
These results confirmed that the proposed modified CTAB protocol is efficient for the extraction of $A$. aculeata DNA from different sources: fresh leaf, lyophilized leaf and stipe. Also, the proposed method has a high repeatability and accuracy which can be seen by the low values of standard deviation observed among DNA samples analyzed by spectrophotometry (Table 1). Moreover, the method is less laborious and safer, since 2-mercaptoethanol was eliminated from this protocol. 2-Mercaptoethanol is volatile and toxic and requires additional care when handled (Molinari and Crochemore, 2001; Sambrook and Russel, 2001).

The stipe is a good source of DNA for molecular biology and genetic studies due to its accessibility, especially in mature wild plants (Novaes et al., 2009). Moreover, lyophilization is a helpful tool when a large number of samples are collected. It allows tissues to be stored for a long period of time for later processing.

\section{ACKNOWLEDGMENTS}

\section{Research supported by Petrobras and CNPq.}

\section{REFERENCES}

Abreu IS, Carvalho CR, Carvalho GMA and Motoi SY (2011). First karyotype, DNA C-value and AT/GC base composition of macaw palm (Acrocomia aculeata, Arecaceae) - a promising plant for biodiesel production. Aust. J. Bot. 59: 149-155.

Barbosa MM (1998). Quantificação e Controle da Qualidade do DNA Genômico. In: Marcadores Moleculares em Plantas (Milach S, ed.). UFRGS, Porto Alegre, 99-106.

Borges DB, Amorim MB, Waldschmidt AM, Mariano-Neto E, et al. (2012). Optimization of DNA extraction from fresh leaf tissues of Melanoxylon brauna (Fabaceae). Genet. Mol. Res. 11: 1586-1591.

Dellaporta SL, Wood J and Hicks JB (1983). A plant minipreparation: version II. Plant Mol. Biol. Rep. 1: 19-20.

Doyle JJT and Doyle JL (1990). Isolation of plant DNA from fresh tissue. Focus 12: 13-15.

Faleiro FG, Araújo IS, Bahia RCS, Santos RF, et al. (2002). Otimização da extração e amplificação de DNA de Theobroma cacao L. visando obtenção de marcadores RAPD. Agrotrópica 14: 31-34.

Ferreira ME and Grattapaglia D (1998). Introdução ao Uso de Marcadores Moleculares em Análise Genética. $3^{\mathrm{a}}$ ed. Embrapa-Cenargen, Brasília.

Henderson A, Galeano G and Bernal R (1995). Field Guide to The Palms of The Americas. Princeton University, New Jersey.

Manfio CE, Motoike SY, Resende MDV, Santos CEM, et al. (2012). Avaliação de progênies de macaúba na fase juvenil e estimativas de parâmetros genéticos e diversidade genética. Pesq. Flor. Bras. 32: 63-68.

Molinari H and Crochemore ML (2001). Extração de dna genômico de Passiflora spp. para análises PCR-RAPD. Rev. Bras. Frutic. 23: 447-450.

Motoike SY and Kuki KN (2009). The potential of macaw palm (Acrocomia aculeata) as source of biodiesel in Brazil. Int. Rev. Chem. Eng. 1: 632-635.

Moura EF, Motoike SY, Ventrella MC, de Sá Júnior AQ, et al. (2009). Somatic embryogenesis in macaw palm (Acrocomia aculeata) from zygotic embryos. Sci. Hortic. 119: 447-454.

Novaes RM, Rodrigues JG and Lovato MB (2009). An efficient protocol for tissue sampling and DNA isolation from the stem bark of Leguminosae trees. Genet. Mol. Res. 8: 86-96.

Nucci SM, Azevedo-Filho JA, Colombo CA, Priolli RH, et al. (2008). Development and characterization of microsatellites markers from the macaw. Mol. Ecol. Resour. 8: 224-226.

Nunes CF, Ferreira JL, Fernandes MCN, Breves SS, et al. (2011). An improved method for genomic DNA extraction from strawberry leaves. Ciênc. Rural 41: 1383-1389.

Sambrook J and and Russel DW (2001). Molecular Cloning: A Laboratory Manual. Cold Spring Harbor Laboratory Press, New York.

Shahzadi I, Ahmed R, Hassan A and Shah MM (2010). Optimization of DNA extraction from seeds and fresh leaf tissues of wild marigold (Tagetes minuta) for polymerase chain reaction analysis. Genet. Mol. Res. 9: 386-393. 